\title{
KEBERHASILAN MELAKUKAN PERUBAHAN MELALUI ADKAR MODEL Studi Kasus Avnet Information Security Company
}

\author{
Elsye Tandelilin (elsgh@yahoo.com) \\ Fakultas Bisnis and Ekonomika Universitas Surabaya
}

\begin{abstract}
There are many forces that are acting as stimulants for change such as socio-cultural, technological, economic and political and the options essentially fall in four categories: structure, physical setting, technology and people. The application of planned changed sometimes create many resistances for many reasons. There are many tactics have been suggested for use by change agents in dealing with resistance to change. One of the best suggestions is ADKAR MODEL (Awareness, Desire, Knowledge, Ability and Reinforcement). The purpose of this article is to illustrate empirically how ADKAR Model is configured to overcome the resistance of change of Avnet's employees. Library researchs were carried out with qualitative approach. The current finding indicate that the application of ADKAR Model was enabled Avnet's change agent to identified why the change was not running well and suggestions to handle it and to identify the changing of many levels (individual, group, inter-group and organization. Another finding was the model can be optimal reached if every step in this model is running well and fully supported by all management teams and also make it successful and permanently embedded into the organizational operations and business model
\end{abstract}

Keywords: Organizational change, Resistance to Change, ADKAR Model

\section{PENDAHULUAN}

Pengelolaan bisnis saat ini membutuhkan lebih banyak kompetensi dari para pebisnis, bila ingin sukses dan berkembang, karena tidak ada satupun perusahaan yang berada dalam lingkungan yang stabil. Globalisasi, deregulasi, kemajuan teknologi informasi dan liberalisasi menciptakan realitas baru yang mejadikan persaingan semakin ketat antar organisasi baik secara domestik maupun internasional dan tidak ada organisasi yang imun terhadap hal ini. Kondisi ini menuntut dilakukannya perubahan di setiap dimensi dan level dalam organisasi, bila ingin sukses dalam persaingan (Greenberg \& Baron: 2000). Janzen (2001) juga menegaskan bahwa organisasi yang tidak mampu melakukan inovasi yang berkelanjutan akan terlindas oleh pesaing yang tidak mengenal kasihan. Organisasi yang tidak mampu mengikuti perubahan lingkungan akan senantiasa mengalami ketertinggalan dan tidak akan pernah menjadi yang terbaik. Oleh karena itu, menghadapi perubahan lingkungan di era turbulen saat ini, membutuhkan pemahaman yang terintegrasi mengenai penyebab terjadinya suatu perubahan.

Menghadapi tuntutan di atas mau tidak mau 'memaksa' organisasi untuk melakukan berbagai perubahan atau mati (change or die). Bateman \& Zeithaml: 1990 mengemukakan bahwa " organizations must change because their environments change". Pernyataan tersebut mengindikasikan bahwa bisnis saat ini sedang dihujani dengan berbagai perubahan yang luar biasa yang bersumber dari berbagai hal, baik berupa tekanan yang datang dari dalam maupun dari luar organisasi.

Kebutuhan akan perubahan seringkali muncul bila organisasi dihadapkan oleh berbagai masalah. Namun, tidak semua organisasi melakukan perubahan karena alasan tersebut. Banyak organisasi terdorong melakukan perubahan dengan alasan-alasan yang positif, terutama pada kondisi adanya 'performance gap' antara kinerja yang diharapkan dengan kinerja aktual (Bateman \& Zeithaml: 1990). Pengakuan akan adanya 'performance gap' 
sering mendorong organisasi untuk melakukan perubahan dan berusaha meningkatkan kinerja pada tingkat yang diharapkan. Namun hasil penelitian dari Maver: 1997 menunjukkan hasil sebaliknya. Alasan umum dari usaha-usaha perubahan yang gagal adalah ketidakmampuan menangani penolakan dari karyawan yang merasa terancam akibat perubahan tersebut, sehingga sulit untuk memperoleh dukungan dan komitmen karyawan untuk mengimplementasikan perubahan. Robbims (2011) juga mengungkapkan bahwa ego manusia itu rapuh dan sering melihat perubahan sebagai suatu ancaman. Walaupun data karyawan menunjukkan bahwa perubahan sangat diperlukan, namun pengakuan karyawan seringkali bertolak belakang bahwa mereka tidak membutuhkan perubahan. Ada berbagai konsep yang dikemukakan oleh para pakar untuk menangani penolakan secara efektif. Salah satunya konsep yang dikemukakan oleh Jeffrey M. Hiatt (2006) adalah ADKAR Model yang dipakai untuk menangani perubahan secara efektif.

Salah satu contoh perusahaan yang berhasil melakukan perubahan dengan menerapkan konsep ADKAR model adalah Avnet Information Security Company. Studi kasus: Bagaimana Avnet mengaplikasikan prinsip perubahan manajemen dalam membuat transisi dari perusahan berbasis produk (product - based) ke perusahaan berbasis solusi (solutionbased). Avnet Information Security merupakan sebuah perusahaan IT security yang beroperasi di seluruh dunia dan merupakan perusahaan swasta yang mengkhususkan diri dalam penyediaan informasi solusi keamanan yang lengkap untuk kebutuhan bisnis, baik untuk bidang perbankan, manufaktur, asuransi, investasi, industry pengolahan, dan pasar teknologi di seluruh dunia. Tujuan Avnet adalah untuk membantu perusahaan merancang dan mengintegrasikan security ke infrastuktur IT perusahaan dengan cara yang mendukung strategi bisnis perusahaan. Avnet juga memberikan keunggulan dalam keamanan IT melalui system teknologi operasional dan solusi sistem keamanan melalui perencanaan, pendampingan dan pengujian system informasi dan telekomunikasi yang mampu menjawab kebutuhan keamanan perusahaan saat ini dan kebutuhan perubahan di masa yang akan datang. Saat ini Avnet memiliki lebih dari 300 pelanggan di seluruh dunia dan memiliki tim yang berpengalaman dari berbagai disiplin ilmu yang kerjanya didasarkan pada pendekatan holistic sehingga memungkinkan perusahaan berjalan dengan efektif, mengurangi resiko dan kerugian yang berkaitan dengan kerahasiaan, ketersediaan, keterandalan dari aset informasi, teknologi dan proses perusahaan.

Karena perubahan yang dimanis dalam bisnis informasi keamanan IT sangatlah tinggi, maka Avnet memutuskan untuk melakukan perubahan dari perusahaan yang semula berbasis produk ke perusahaan yang berbasis solusi. Untuk merealisasikan perubahan tersebut, Avnet melakukan jajak pendapat dan bertanya mengenai apa tantangan terbesar dari sebuah perubahan bisnis yang semula berorientasi pada produk ke orientasi konsumen (pendekatan berorientasi solusi). Hasilnya menunjukkan sebagian besar responden mengatakan bahwa tuntutan terbesar dan tersulit ada pada pengelolaan perubahan budaya dan perilaku.

Berdasarkan kasus diatas, maka dapat dibuat perumusan masalah sebagai berikut: "Bagaimana implementasi keberhasilan melakukan perubahan melalui ADKAR Model pada perusahaan Avnet Information Security?" Adapun tujuan dari penelitian ini adalah untuk memahami dan mendeskripsikan perubahan yang dilakukan dengan mmodel AKDAR di perusahaan Avnet Information Security. Sedangkan manfaatnya untuk pengembangan teori di bidang change management dan untuk pengembangan wawasan dalam praktik bisnis. 


\section{LANDASAN TEORI DAN PENGEMBANGAN HIPOTESIS}

\section{Organizational Change}

Greenberg and Baron (2000) mendefinisikan organizational change sebagai "planned or unplanned transformations in an organization's structure, technology and people". Hal senada juga dikemukakan oleh Robbins and Coulter (2007) yang mengatakan "organizational change is any alteration of people, structure or technology". Dari definisidefinisi di atas dapat disimpulkan bahwa perubahan organisasi dapat dilakukan baik secara terencana maupun tidak yang meliputi beberapa aspek yaitu struktur, teknologi maupun orang.

Adapun pemicu perubahan dapat bervariasi, yaitu (1) FaKtor ekonomi seperti persaingan, tingkat pengangguran, nilai mata uangm kebijakan pemerintah di bidang ekonomi, dan lain sebagainya. (2) Faktor teknologi seperti proses komputerisasi, perubahan dalam teknologi transportasi, proses produksi yang baru dan perkembangan teknologi informasi/internet. (3) Faktor politik seperti ideologi dan peraturan pemerintah, hukum internasional, hukum tentang perpajakan, dan aktivitas serikat perdagangan. (4) Faktor sosial-budaya, seperti tren demografi, perubahan gaya hidup, masalah-masalah gender, keperdulian terhadap lingkungan dan etika bisnis.

Lebih lanjut, Bateman \& Zeithaml (1990) mengidentifikasi ada 4 area utama dari perubahan organisasi, yaitu: (1) Strategy: perubahan strategi merupakan kunci, karena akan berdampak pada perubahan area lainnya. Ada 3 tahapan dasar bagi organisasi untuk membuat suatu perubahan strategi, yaitu (a) menyadari bahwa strategi yang ada saat ini tidak lagi sesuai dengan kondisi organisasi; (b) menetapkan suatu visi sebagai arahan organisasi di masa mendatang dan (c) mengimplementasikan perubahan dengan menyusun sistem yang baru untuk mendukung perubahan tersebut ; (2) Technology: terkait dengan pendekatan teknologi apa yang dibutuhkan dalam perubahan; (3) Structural: perubahan struktural dapat terjadi karena adanya perubahan strategi yang menyebabkan seluruh operasi/sistem organisasi dan gaya manajemen juga berubah; (4) People: Perubahan atas SDM perlu dilakukan apabila terjadi perubahan dari ke 3 aspek yang diuraikan sebelumnya, maupun untuk merubah sikap dan perilaku kerja dengan tujuan untuk meningkatkan efektivitas kerja. Perubahan strategi, teknologi dan perubahan lainnya dalam lingkungan kerja akan mempengaruhi sikap seseorang (kadangkala dengan cara yang negatif). Dalam kenyataannya, merubah SDM merupakan hal tersulit dan terpenting dari seluruh perubahan yang terjadi dalam suatu organisasi, karena dari ke3 aspek di atas SDM lah yang bisa menolak untuk melakukan perubahan.

\section{Resistance To Change}

Betapapun kecilnya perubahan yang dilakukan organisasi selalu membawa konsekuensi positif dan negatif bagi para karyawan. Penolakan terhadap perubahan merupakan suatu reaksi yang normal dari individu dan kelompok, karena mereka telah memiliki kebiasaan tertentu yang seringkali sulit diubah. Penolakan atas perubahan, sebagian besar merupakan hasil dari ketidakpahaman karyawan atas strategi organisasi, karyawan memiliki perspektif yang berbeda dengan pihak manajemen tentang perubahan yang terjadi, tidak memahami maksud/tujuan dari perubahan, karyawan tidak dilibatkan dalam rencana perubahan, karyawan merasa bahwa inisiatif perubahan tidak sesuai dengan masalah yang ada serta tidak cukup kuat dipakai sebagai alasan dilakukannya suatu perubahan, perubahan tidak dibuat dengan jelas terutama kepada orang-orang yang nantinya akan dipengaruhi oleh perubahan tersebut, perubahan yang dibuat sangat ambigu sehingga muncul berbagai interpretasi yang berbeda-beda, perubahan dibuat atas dasar pertimbangan pribadi, dan perubahan yang ada tidak memperhatikan kelompok-kelompok yang telah mapan dalam organisasi. 
Folger \& Skarlicki (1999) mengemukakan bahwa perubahan organisasi dapat menghasilkan sikap skeptis dan penolakan dari karyawan, sehingga menyebabkan perubahan yang dibuat menjadi sulit diimplementasikan. Jika manajemen tidak memahami, menerima dan membuat suatu usaha untuk bekerja dengan penolakan, hal tersebut dapat merusak implementasi perubahan. Hal senada juga dikemukakan oleh Coetsee (1999) bahwa kemampuan manajemen untuk mencapai hasil yang maksimal dari suatu perubahan, sangat tergantung pada bagaimana pihak manejerial secara efektif menciptakan dan menjaga iklim yang mampu meminimalkan perilaku penolakan dan mendorong penerimaan dan dukungan karyawan. Namun perlu dicermati oleh para manajer bahwa usaha-usaha yang dilakukan hendaknya diarahkan pada penyebab terjadinya penolakan bukan pada symptom-symptom yang ada.

\section{Resistance Defined}

Untuk memahami konsep employee resistance, sangatlah penting untuk mendefinisikan secara jelas apa itu employee resistance. Zander (1950) (dalam Dent \& Goldberg: 1999) seorang periset awal tentang employee resistance mendefinisikan resistance to change as "behavior which is intended to protect an individual from the effects of real or imaged change". Peneliti lain yaitu Zaltman \& Duncan (1977) (dalam Bradley: 2000) juga mengemukakan hal senada "resistance as any conduct that serves to maintain the status quo in the face of pressure to alter the status quo" Sedangkan Folger \& Skarlicki (1999) mendefinisikan resistance as "employee behavior that seeks to challenge, distrupt or invert prevailing assunptions, discourses and power relations"

Dengan mengacu pada berbagai definisi di atas, Piderit (2000) mengungkapkan bahwa sebenarnya definisi employee resistance memiliki jangkauan (scope) yang luas dan dari hasil penelitiannya terlihat ada 3 perbedaan dari konsep employee resistance yaitu kognitif, emosional dan perilaku. Hal ini didukung oleh sejumlah penelitian pula seperti penelitian yang dilakukan oleh Armenakis, Harris \& Nossholder (1993) yang mendefinisikan employee resistance dalam konteks perilaku, Coch \& French (1948) serta Argyris \& Schon (1974) dan Argyris \& Schon (1978) (dalam piderit: 2000) yang mendefinisikan employee resistance dari sisi emosional dan melihat penolakan atas perubahan sebagai suatu mekanisme pertahanan diri yang disebabkan oleh rasa frustasi dan kecemasan. Sedangkan penelitian terkait dengan aspek perilaku dilakukan oleh Brower \& Abolafia (1995) (dalam Piderit: 2000) yang mendefinisikan "resistance as a particular kind of action or inaction" Lebih lanjut, Ashforth \& Mael:1998 juga mendefinisikan "esistance as intentional acts of commision (defiance) or ommision".

Menurut Dent \& Goldberg (1999), sebenarnya seseorang tidaklah benar-benar menolak perubahan, tetapi yang ditolak adalah kehilangan status, kehilangan pembayaran, atau kehilangan kenyamanan yang diakibatkan oleh perubahan tersebut. Hal ini berarti dengan memahami penyebab penolakan karyawan atas perubahan, manajemen dapat mengambil langkah-langkah yang tepat untuk mengatasi setiap penolakan.

\section{The Nature \& Causes of Resistance}

Symptom dalam konteks ini merupakan perilaku tertentu yang individu tunjukkan apabila mereka menolak adanya perubahan. Hultman (1995) mengatakan bahwa penting untuk membedakan antara symptom dari penolakan atas perubahan dan penyebab yang berada dibelakangnya. Perilaku tersebut dibagi menjadi 2 kategori, yaitu active resistance symptom misalnya sengaja melakukan kesalahan, menampakkan ketakutan, dan melakukan manipulasi dan passive resistance symptom, misalnya menyetujui secara verbal, tetapi tidak diikuti dengan tindakan, berpura-pura tidak mengindahkan, dan menahan informasi. Untuk mendiagnosis penyebab-penyebab penolakan, haruslah dipahami pola 
pikir dari individu tersebut karena mencerminkan nilai-nilai yang dimilikinya. Ada sejumlah alasan mengapa individu menolak perubahan, antara lain: (a) karena perubahan mengharuskan seseorang harus mempelajari hal-hal baru; (b) ketakutan akan masa depan yang tidak pasti akibat perubahan tersebut; (c) harus meninggalkan sesuatu yang sudah familiar; (d) takut kehilangan jabatan atau status yang dimilikinya; (e) ketakutan kehilangan penghasilan (faktor ekonomi) dan (f) takut kehilangan kontak sosial (dimensi sosial).

\section{Positive Resistance}

Para manajer sering menerima penolakan secara negatif dan karyawan yang melakukan penolakan tersebut dipandang sebagai karyawan yang tidak patuh dan menjadi penghalang bagi organisasi dan harus segera diatasi agar tujuan dari perubahan dapat tercapai. Namun penolakan karyawan atas perubahan tidaklah selalu bersifat negatif, artinya penolakan tersebut dapat berdampak positif dan berguna bagi perubahan organisasi. Dengan penuh wawasan dan debat positif, kritik-kritik yang membangun serta ketidaksetujuan, tidaklah bermakna sama dengan penolakan yang bersifat negatif. Justru dengan positive resistance, dapat menghasilkan pemahaman yang lebih baik serta menambah opsi dan solusi yang bermanfaat.

Argumen ini diperkuat dengan pernyataan Piderit (2000) bahwa penolakan karyawan mungkin akan mendorong manajemen untuk berpikir kembali atau mengevaluasi kembali inisiatif perubahan yang diambil. Penolakan tersebut juga berfungsi sebagai pintu masuk atau filter yang membantu organisasi menyeleksi semua kemungkinan perubahan yang paling tepat untuk situasi yang ada.

\section{Model-Model Untuk Mengatasi Penolakan Terhadap Perubahan}

Ada berbagai cara yang dapat digunakan manajemen untuk mengatasi penolakan karyawan atas perubahan. Robbins and Judge (2010) mengemukakan 8 taktik yang dapat di pakai change agent untuk mengatasi penolakan terhadap perubahan yaitu melalui:

1. Pendidikan dan Komunikasi (Education \& Communication): penolakan dapat diminimalkan melalui komunikasi untuk membantu karyawan melihat logika perubahan. Asumsi dari taktik ini apabila sumber penolakan terletak dalam kesalahan informasi atau komunikasi yang buruk.

2. Partisipasi (Participation): sukar bagi individu-individu untuk menolak suatu keputusan perubahan kalau mereka dilibatkan dalam keputusan tersebut. Asumsinya para peserta mempunyai keahlian untuk memberikan sumbangan yang berarti, keterlibatan mereka dapat mengurangi penolakan, memperoleh komitmen dan meningkatkan kualitas keputusan akan perubahan.

3. Membangun Dukungan dan Komitmen (Building Support \& Commitment): change agent dapat menawarkan berbagai upaya/dukungan untuk mengurangi penolakan. Misalnya dengan memberikan konseling dan terapi kepada karyawan yang cemas akibat perubahan tersebut, memberikan pelatihan ketrampilan baru ataupun cuti pendek yang dibayar untuk memudahkan penyesuaian terhadap perubahan. Kelemahan dari taktik ini adalah mengkonsumsi banyak waktu dan pelaksanaannya tidak dijamin keberhasilannya.

4. Mengembangkan Hubungan Yang positif (Develop Positive Relationships)

Orang lebih percaya untuk menerima perubahan jika mereka percaya bahwa para manajer memang mengimplementasikannya. Hal ini dapat menimbulkan hubungan yang positif dengan atasan serta sikap positif tentang proses perubahan itu sendiri.

5. Mengimplementasikan Perubahan secara Fair (Implementing Chnges Fairly): Salah satu cara organisasi dapat meminimalkan dampak negative adalah menyakinkan bahwa perubahan diimplementasikan secara fair dan konsisten. Di semua unit dan level yang ada dalam organisasi. 
6. Manipulasi dan Kooptasi (Manipulation \& Cooptation): manipulasi mengacu pada upaya pengaruh yang tersembunyi. Memuntir dan memutarbalikkan fakta untuk membuat fakta tampak menarik, menahan informasi yang tidak diinginkan dan menciptakan rumor palsu agar para karyawan menerima dengan baik suatu perubahan. Sedangkan kooptasi merupakan bentuk manipulasi dan partisipasi yaitu upaya menyuap pemimpin kelompok penolak dengan memberikan peran utama dalam keputusan perubahan dengan maksud untuk memperoleh dukungan dan bukan untuk mencari keputusan yang lebih baik. Cara ini merupakan yang paling mudah untuk memperoleh dukungan tetapi dapat menjadi bumerang jika karyawan menyadari dirinya diperalat, maka dapat memperburuk kredibilitas change agent.

7. Memilih Orang Yang Menerima Perubahan (Selecting People Who Accept Change) : Riset menunjukkan bahwa kemampuan menerima dan beradaptasi terhadap perubahan dengan mudah merupakan bagian dari personality seseorang. Artinya ada orang yang memiliki sikap positif terhadap perubahan, terbuka untuk pengalaman baru, mau mengambil resiko serta fleksibel dalam perilaku dibandingkan dengan yang lain. Hal tersebut menunjukkan bahwa organisasi dapat memfasilitasi perubahan dengan memilih orang cenderung menerimanya

8. Pemaksaan (Coersive): merupakan penerapan ancaman atau kekuatan langsung terhadap penolak, misalnya ancaman ditransfer, hilangnya peluang promosi, evaluasi kinerja yang negatif atau surat rekomendasi yang buruk. Kelemahan menggunakan taktik ini, karyawan hanya melakukan perubahan dengan terpaksa dan kredibilitas change agent menjadi jelek.

Cara lain untuk mengatasi penolakan dikemukakan oleh Kurt-Lewin dengan Lewin's ThreeStep Model (Robbins and Judge: 2010), yaitu: (1) Tahap 1 (Unfreezing): artinya membuat situasi yang tepat untuk terjadinya perubahan. Pada tahap ini stabilitas perlu dilemahkan yang berarti dicairkan terlebih dahulu. Kunci dalam tahap unfreezing ini adalah mengenali/mengakui perubahan baik ditingkat individu maupun ditingkat kelompok dan hal tersebut merupakan sebuah proses psikologis yang dinamis dan mendalam; (2) Tahap 2 (Movement): tahap menciptakan inspirasi untuk belajar tetapi tidak melakukan pengendalian atau memprediksi arah perubahan. Dalam tahap ini, organisasi harus mengimplementasikan perubahan secara cepat dan ketika perubahan terjadi dan berhasil, maka perubahan tersebut harus segera di refrozen sehingga dapat bertahan lama; (3) Tahap 3 (Refreezing): adalah tahap untuk menciptakan suasana yang stabil dan mengembalikan tingkat kenyamanan seperti sediakala. Tahap ini bertujuan agar perubahan yang dilakukan bertahan dan karyawan tidak kembali pada pola kerja/ kebiasaan yang lama. Hal tersebut penting dilakukan karena perilaku individu tidak akan bertahan kecuali rutinitas dan norma kelompok juga telah ditransformasikan dan dibentuk. Oleh karena itu melakukan perubahan berarti juga merubah norma-norma, budaya, praktik dan kebijakan organisasi.

Salah satu model lain yang ditawarkan adalah ADKAR Model. ADKAR Model merupakan change management model yang berorientasi pada tujuan (goal) dimana tim manajemen perubahan menfokuskan aktivitas mereka atas hasil tertentu. Aplikasi dari ADKAR Model ditujukan untuk perubahan yang terencana (planned change) dan model ini dapat digunakan untuk: mendiagnosis penolakan karyawan atas perubahan, membantu transisi karyawan melewati proses perubahan, menciptakan suatu rencana tindakan (action plan) yang berhasil bagi pengembangan pribadi selama perubahan, dan mengembangkan change management plan bagi para karyawan. Agar penggunaan ADKAR Model dapat efektif, perlu dipahami framework yang mendasarinya. Perubahan dapat terjadi pada 2 dimensi yaitu dimensi bisnis (business dimension) dan dimensi orang (people dimension). Keberhasilan akan suatu perubahan dapat terjadi apabila kedua dimensi perubahan tersebut terjadi secara simultan. 


\section{Business Dimension of Change}

Adapun elemen-elemen yang tercakup dalam dimensi bisnis, lebih banyak terkait dengan adanya new process, systems maupun struktur organisasi, yang telah diimplementasikan ke dalam organisasi.

\section{People Dimension of Change}

Riset menunjukkan bahwa dalam melakukan suatu perubahan, problem yang muncul lebih banyak terkait dengan dimensi orang daripada dengan dimensi bisnis dan hal ini sering menjadi penyebab kegagalan suatu perubahan.

ADKAR Model ditujukan untuk mengelola people dimension of change. Adapun elemenelemen dalam ADKAR Model adalah sebagai berikut: (1) Awareness - kesadaran akan kebutuhan terhadap perubahan; (2) Desire - keinginan untuk berpartisipasi dan mendukung perubahan; (3) Knowledge - pengetahuan bagaimana melakukan perubahan; (4) Ability- kemampuan untuk mengimplementasikan perubahan (new skills and behaviors) berbasis day to day; dan (5) Reinforcement- penguatan untuk menjaga perubahan yang telah dibuat/terjadi.

\section{METODE PENELITIAN}

Penelitian ini menggunakan jenis penelitian kualitatif, yang menurut Stauss dan Corbin (2003) merupakan jenis penelitian yang temuan-temuannya tidak diperoleh melalui prosedur statistic atau bentuk hitungan lainnya. Sedangkan focus pada penelitian ini ada pada kajian aplikasi Adkar Model dalam menangani perubahan secara efektif pada Avnet Information Security Company. Pengumpulan data dalam penelitian kualitatif ini menggunakan model penelitian yang bersifat library research / riset kepustakaan. Hal ini dilakukan dengan mengkaji berbagai literature dan dokumentasi, membuat catatan serta komentar terhadap data yang relevan dengan materi yang diteliti, membuat memo/rangkuman data dengan tahapan secara reflektif melalui kompilasi berbagai temuan dan memanfaatkan analogi, konsep serta intepretasi data. Data lapangan diperoleh melalui situs Avnet.com

\section{HASIL DAN PEMBAHASAN}

Pada kasus perusahaan Avnet di atas, Avnet akhirnya memutuskan untuk menggunakan ADKAR Model, karena cara penolakan yang ditawarkan dalam model Lewin dinilai memiliki beberapa kelemahan, antara lain: (1) pendekatan Lewin merupakan pendekatan terencana yang terlalu sederhana dan mekanistik yang cocok untuk perubahan organisasi yang terjadi sehari-hari, tetapi tidak cocok untuk sebuah organisasi besar yang memiliki inovasi tinggi, (2) pendekatan Lewin lebih banyak menawarkan pendekatan top-down dalam melakukan perubahan dan mengabaikan situasi yang memerlukan pendekatan perubahan bottom-up, (3) tiga langkah model Lewin hanya dapat digunakan bila ada tujuan jangka pendek yang hendak dicapai., karena orang cenderung akan menolak perubahan jika manfaat dalam jangka pendek tidak bisa dirasakan, (4) perusahaan harus menetapkan tujuan dan sasaran perubahan dengan jelas dan menyediakan reward bagi orang-orang yang terlibat melalui pengakuan, promosi ataupun vang, bila semua ini tidak jelas, maka perubahan sulit dilakukan, (5) change agent harus menggunakan kompetensi tertentu seperti team working, problem solving dan effective communication dalam melakukan perubahan.

Sedangkan 8 taktik yang dikemukakan oleh Robbins dan Judge juga memiliki beberapa kelemahan, antara lain: cara-cara di atas hanya melihat penyebab penolakan secara parsial, sulit diterapkan secara maksimal bila penyebab penolakan lebih dari satu, sulit diterapkan pada kondisi heterogenitas penyebab penolakan yang tinggi dan keberhasilan 
penerapannya bersifat temporary karena tidak bermula dari kesadaran dan keinginan karyawan untuk berubah.

ADKAR model menawarkan berbagai keunggulan dibandingkan dengan model-model di atas, antara lain memiliki kemampuan mengidentifikasi mengapa perubahan tidak berjalan dengan baik dan langkah-langkah apa yang perlu dibuat agar perubahan tersebut bisa berhasil. Di dalam ADKAR Model, perubahan di break down menjadi bagian yang kecil, memahami di bagian mana perubahan gagal dilakukan dan dampak yang ditimbulkan dari penolakan tersebut. Model ini juga dapat dipakai untuk melakukan perubahan baik di level individu, kelompok, inter-group, maupun di level organisasi dan dampak dari keberhasilan penerapan model ini akan bersifat permanen karena perubahan itu terjadi bermula dari kesadaran dan keinginan untuk berubah serta dilengkapi dengan pengetahuan, kemampuan dan penguatan berupa reward.

Meskipun menyadari bahwa kesulitan terbesar dalam melakukan perubahan ada pada perubahan budaya dan perilaku karyawan, pimpinan Avnet tetap memutuskan untuk melakukan perubahan, karena tuntutan dan perkembangan teknologi di bidang IT security tidak bisa dihindari. Namun pemilihan model ADKAR mendatangkan keberhasilan. Adapun aplikasi model ADKAR dalam proses perubahan yang dilakukan Avnet adalah sebagai berikut:

\section{AWARENESS}

Awareness merupakan langkah awal dalam model ADKAR, dimana organisasi perlu menumbuhkan kesadaran kebutuhan akan perubahan. Tahap ini pun dilakukan oleh change agent Avnet dengan cara melakukan sosialisasi tentang rencana perubahan. Ada 4 elemen utama dari awareness, yaitu:

\section{a. Key Messages}

Sewaktu menciptakan kesadaran kebutuhan akan perubahan, change agent dari Avnet mengkomunikasikan key messages yang meliputi: (1) Messages tentang kondisi bisnis Avnet saat ini yang terdiri dari situasi saat ini dan alasan yang rasional bagi Avnet untuk melakukan perubahan, yaitu tingginya tingkat persaingan di bidang IT Security, keinginan konsumen untuk mendapatkan produk dan layanan yang lebih prima, kondisi keuangan organisasi dan konsekuensi yang akan terjadi bila perubahan tidak dilakukan Avnet; (2) Messages tentang perubahan, yang meliputi visi Avnet setelah perubahan dilakukan, jangkauan perubahan (proses, organisasi, sistem dan teknologi), sasaran dari perubahan, keseluruhan timeframe untuk mengimplementasikan perubahan, menyatukan perubahan dengan strategi bisnis, seberapa besar perubahan dibutuhkan, siapa yang paling dipengaruhi dan tidak dipengaruhi oleh perubahan tersebut dan apa yang harus berubah, bagaimana dan kapan perubahan dilakukan termasuk apa yang tidak perlu berubah di Avnet; (3) Messages tentang bagaimana dampak perubahan bagi karyawan Avnet, yang meliputi dampak perubahan atas aktivitas sehari-hari dari setiap karyawan Avnet, implikasi perubahan atas job security, aktivitas dan perilaku tertentu yang diharapkan dari karyawan Avnet termasuk dukungan atas perubahan, prosedur untuk memperoleh bantuan selama dilakukannya perubahan dan cara-cara memberikan umpan balik kepada seluruh karyawan Avnet; (4) Memperbaharui status dan laporan progresitas yang meliputi: jadwal perubahan secara keseluruhan, kapan informasi baru tersedia, bagaimana informasi tentang perubahan dibagikan dan point-point keputusan utama tentang perubahan.

Meskipun ada guidance tentang bagimana key messages dilakukan namun para pimpinan Avnet menyadari hal tersebut tidaklah menjawab semua masalah yang muncul dalam melakukan suatu perubahan. Hal penting yang harus dilakukan change agent Avnet adalah bagaimana menyampaikan messages terutama bila jawabannya tidak diketahui saat dan kapan informasi tambahan akan tersedia untuk menjawab pernyataan para karyawan. 


\section{b. Channels For Building Awareness}

Komunikasi manajemen adalah metode yang paling umum digunakan untuk menciptakan kesadaran kebutuhan akan perubahan. Komunikasi yang dilakukan oleh change agent Avnet, antara lain:

1. Face-to-Face - meliputi antara lain: group meetings, focus groups, road show presentations, team meetings dan training courses \& workshops.

2. Alternate Communication Channels - meliputi antara lain ; emails, demonstrations, internal memos, videos, website (intranet), posters, newletter, dan leaflets

Hal penting yang disadari oleh para pimpinan Avnet adalah kehati-hatian dalam memilih saluran komunikasi, karena disadari bahwa keberhasilan melakukan perubahan sangat tergantung pada pemilihan saluran komunikasi yang tepat sesuai dengan waktu penggunaannya serta memperhatikan dampak dari message yang disampaikan kepada audience / karyawannya. Misalnya Avnet tidak akan menggunakan email bila layoff merupakan bagian dari perubahan yang terjadi.

\section{c. Timing and Audiences}

Para pimpinan Avnet juga menyadari bahwa pada waktu membangun kesadaran kebutuhan akan perubahan, waktu adalah hal vital yang harus diperhatikan. Semakin lama karyawan berada dalam proses perubahan, semakin besar pula dampaknya terhadap produktivitas dan konsumen secara menyeluruh. Untuk itu informasi tentang perubahan hendaknya disampaikan secara jelas kepada karyawan dan bila tidak dilakukan akan sangat beresiko bagi Avnet terutama bila karyawan sendiri yang mengetahui dan memahami perubahan tersebut. Bahkan lebih lanjut, Avnet akan kehilangan peluang untuk melibatkan karyawan dalam mendisain keseluruhan perubahan. Untuk itu timing yang tepat adalah pada saat kesadaran akan perubahan muncul.

Selain faktor timing, faktor audience juga harus mendapat perhatian. Dalam menghadapi perubahan, change agent Avnet membagi karyawan dalam 3 kelompok, yaitu kelompok1 adalah kelompok yang terbuka dan menginginkan perubahan, kelompok ke-2 adalah adalah kelompok uncertain dan ragu-ragu terhadap perubahan dan kelompok yang ke-3 adalah kelompok yang tidak ingin berubah. Distribusi dari ketiga kelompok di atas ternyata sangat bervariasi di Avnet. Begitu pula disadari bahwa dampak dari berbagai kombinasi ketiga jenis kelompok di atas berbeda-beda, mulai dari dampak yang paling kecil sampai yang kompleks, sehingga cara untuk menangani ketiga kelompok di atas juga berbedabeda pula.

\section{DESIRE}

\section{a. Building Desire}

Dalam kenyataannya pimpinan Avnet tidak dapat mendikte ataupun mengontrol keinginan karyawannya untuk berubah ataupun tidak berubah. Tetapi apapun pilihan karyawan tidaklah berarti pimpinan Avnet tidak memiliki power untuk mencapai hasil tertentu secara bersama-sama. Pimpinan Avnet menyadari ada sejumlah elemen yang dapat menciptakan keinginan karyawannya untuk berubah, dan hasil interview dan diskusi dengan para karyawan ditemukan beberapa hal yang dapat memicu karyawan untuk berubah antara lain ketakutan kehilangan pekerjaan, ketidakpuasan dengan situasi saat ini, potensi terjadinya konsekuensi negative, adanya afiliasi dan sense of belonging, adanya pengembangan karir, insentif atau kompensasi dan harapan akan kondisi yang lebih baik di masa yang akan datang.

\section{b. Personal and Organizational Context for Change}

Dalam memunculkan keinginan untuk berpartisipasi terhadap perubahan, pimpinan Avnet memperhatikan pula motivating factors yang diberikan, baik positive maupun negative motivating factors. Pimpinan Avnet menyadari bahwa kedua hal tersebut akan dievaluasi oleh karyawan dalam konteks personal seperti situasi keluarga (kesehatan, posisi keuangan, 
hubungan yang dimiliki, stabilitas dan lain sebagainya), pengalaman dan rencana karir pribadi (keberhasilan, kegagalan, promosi dan lain sebagainya), dan derajat dari perubahan yang akan mempengaruhi karyawan secara pribadi. Lebih lanjut, disadari pula bahwa selain mengevaluasi positive dan negative motivating factors dalam personal context, para karyawan juga perlu mengevaluasi dalam konteks organisasi. Dari beberapa interview dengan para karyawan Avnet, ditemukan perubahan dalam konteks organisasi hendaknya didasarkan pada sejarah perubahan organisasi (kesuksesan dan kegagalan perubahan di masa lalu) dan nilai-nilai serta budaya organisasi (bagaimana perlakuan Avnet company terhadap karyawannya dan bagaimana karyawan memperlakukan sesamanya).

\section{c. Methods for Creating a Desire to Change}

Ada 10 metode utama untuk menciptakan keinginan untuk berubah dalam ADKAR Model. Namun langkah pertama sebelum menggunakan metode tersebut pimpinan Avnet memastikan bahwa tiap karyawan telah menyadari kebutuhan akan perubahan. Meskipun metode-metode yang dikemukakan dilengkapi dengan berbagai teknik, tidaklah berarti metode-metode ini merupakan "all in one solution" (satu solusi untuk semua masalah), karena dalam aplikasinya akan memunculkan tindakan dan hasil yang berbeda-beda pula, Untuk itu, pimpinan Avnet sangat berhati-hati dalam memilih pendekatan yang tepat untuk tiap situasi dan kondisi yang dihadapi. Adapun ke 10 metode tersebut adalah sebagai berikut:

\section{Method 1: Listen and Understand Objections}

Pimpinan Avnet menyadari bahwa langkah kritis dalam menciptakan keinginan untuk perubahan adalah listen. Karena pengalaman masa lalu menunjukkan bahwa penolakan dalam melakukan perubahan sering bermuara dari keinginan karyawan untuk didengar mengenai keberatan-keberatan mereka akan perubahan. Dalam sesi ini, para change agent Avnet nerusaha menghindari debat dengan karyawan karena tujuan dari proses ini adalah mendengarkan dan memahami serta menyediakan kejelasan informasi tentang suatu perubahan yang dilakukan Avnet, dan bukan membujuk/menyakinkan karyawan untuk mau melakukan perubahan tersebut. Dengan kata lain, para pimpinan Avnet memberikan waktu bagi karyawannya untuk melewati masa transisi dan tidak mencoba melakukan perubahan dalam 1 kali pertemuan.

\section{Method 2: Focus on the "What" and Let Go of the "How"}

Langkah ke2 yang dilakukan para pimpinan Avnet adalah mengkomunikasikan secara sederhana "apa" yang perlu berubah dan membiarkan "bagaimana" karyawan melakukan perubahan tersebut. Proses ini ternyata memunculkan rasa memiliki karyawan Avnet atas perubahan. Jadi, tugas pimpinan Avnet adalah men-share-kan dengan jelas kepada karyawan mengenai visi, tujuan yang ingin diraih dan timelines. Proses sharing-pun dapat berlangsung dengan baik, karena tim yang digunakan di Avnet bersifat cross functional team dengan berbagai disiplin ilmu, sehingga sharing informasi mudah dilakukan.

\section{Method 3: Remove Barriers}

Agar proses perubahan yang dilakukan Avnet bisa berjalan dengan baik, change agent team mulai mengidentifikasi hambatan-hambatan yang mungkin muncul, baik hambatan pribadi seperti keluarga, masalah pribadi, dan keterbatasan fisik atau keuangan, maupun hambatan-hambatan yang tersembunyi di masa lalu.

\section{Method 4: Provide Simple, Clear Choices and Consequences}

Agar proses Building desire dapat berjalan dengan baik, Pimpinan Avnet memberikan pilihan yang sederhana kepada para karyawannya disertai dengan konsekuensi untuk tiaptiap pilihan dan membiarkan karyawan untuk memilih sendiri dan mengendalikan semua pilihannya sendiri. 


\section{Method 5: Create Hope}

Pimpinan Avnet menyadari bahwa karyawan akan meresponi perubahan dengan baik bila mereka melihat peluang untuk sesuatu yang baik di masa mendatang, dan mereka memiliki harapan mencapainya. Oleh karena itu pimpinan Avnet menggunakan pola kepimpinan partisipatif, dimana karyawan diajak berdiskusi tentang keinginan dan harapan-harapan mereka akan perubahan serta harapan akan masa depan yang lebih baik bagi karyawan dan organisasi.

\section{Method 6: Show the Benefits in Areas and Tangible Way}

Bagi kebanyakan karyawan, prinsip 'lihat dulu baru percaya' sering menjadi motto hidup mereka. Oleh karena itu pimpinan Avnet memutuskan untuk mendemonstrasikan benefits of change yang nyata sehingga dapat menciptakan keinginan karyawan untuk berubah. Adapun cara-cara yang dilakukan antara lain men-sharing-kan studi kasus-studi kasus pada organisasi lain yang telah sukses melakukan perubahan yang sama serta hasil yang telah dicapai, mengundang pemimpin-pemimpin organisasi lain untuk menceritakan bagaimana jenis perubahan yang sama dapat mendatangkan keberhasilan bagi organisasi mereka, dan mendemonstrasikan secara nyata keberhasilan akan uji coba perubahan yang telah dilakukan Avnet pada salah satu unit kerja tertentu. Semua proses ini dilakukan oleh pimpinan Avnet untuk mengatasi keragu-raguan dan ketakutan dari karyawan akan perubahan.

\section{Method 7: Make a Personal Appeal}

Para pimpinan Avnet menggunakan kedekatan personal untuk menciptakan keinginan dan dukungan akan perubahan. Personal appeal bisa berjalan dengan baik, karena ada kejujuran (honest) dan hubungan yang terbuka (open relationships) dari pimpinan Avnet, sehingga tingkat trust dan respect dari karyawan juga tinggi.

\section{Method 8: Convert the Strongest Dissenters}

Pimpinan Avnet juga menyadari bahwa dalam diri setiap individu pasti memiliki opini yang berbeda tentang leaders, sehingga bila ada individu-individu yang vokal dan secara keras menolak perubahan, maka akan berdampak negatif pada banyak karyawan Avnet lainnya. Untuk menghadapi karyawan-karyawan tipe ini, pimpinan Avnet menggunakan taktik dan intervensi untuk merubah para karyawan yang menolak menjadi pendukung perubahan. Prinsip yang dipegang oleh pimpinan Avnet adalah bagaimana merubah strong resistors menjadi strong adcocates (penyokong yang kuat akan perubahan) sehingga mereka dapat mempengaruhi karyawan lainnya.

\section{Method 9: Create a Sacrifice}

Untuk metode ke 9 dari proses ADKAR Model ini yaitu menciptakan "sacrifical lamb" tidak digunakan oleh Avnet, karena perubahan yang dilakukan mendapat dukungan sepenuhnya dari para manajer di berbagai level. Metode ini hanya efektif bila terjadi penolakan dari key managers, sehingga perusahaan terpaksa menyediakan termination packeges seperti menawarkan pensiun lebih awal ataupun sejumlah program lain yang lebih baik bagi para manajer yang memilih keluar dari organisasi. Metode ini disadari tidak menjadi suatu standar praktik, artinya metode ini seharusnya digunakan setelah opsi yang lain gagal diterapkan dan perubahan yang dilakukan sangat beresiko.

\section{Method 10: Use Money or Power}

Opsi terakhir yang dipilih Avnet bila opsi-opsi lainnya tidak berjalan baik adalah menggunakan pemberian insentf. Adapun jenis insentif yang dapat diberikan, berupa peningkatan kompensasi atau menciptakan program bonus dimana karyawan diberi penghargaan secara langsung setelah selesai melakukan perubahan dengan sukses, menawarkan promosi ke posisi yang diinginkan. Bargain dalam hal ini disadari pimpinan Avnet sangat diperlukan untuk memindahkan berbagai penolakan karyawan dan merubahnya menjadi dukungan. Dalam kondisi ini, uang dan posisi merupakan alat yang dapat menciptakan keinginan untuk mendukung perubahan. 


\section{KNOWLEDGE}

\section{a. The Role of Knowledge}

Pimpinan Avnet menyadari bahwa pembelajaran tentang perubahan dan informasi tentang bagaimana melakukan perubahan perlu diketahui oleh para karyawan Avnet., Para karyawan perlu memahami apa yang akan berbeda dan yang tidak, baik itu hal-hal baru dalam proses bisnis, prosedur kerja baru, jabatan-jabatan baru, skill baru yang dibutuhkan maupun sistem kerja yang baru. Pimpinan Avnet juga menyediakan media informasi melalui jaringan internet yang dapat diakses oleh semua karyawan yang ingin memngetahui tentang perubahan, karena pimpinan Avnet tidak ingin kevakuman pengetahuan tentang perubahan diisi oleh berbagai rumor dan informasi yang salah.

\section{b. Creating Knowledge}

Selain menyediakan informasi melalui media internet, pimpinan Avnet juga melakukan pelatihan formal di kelas dan web-based online training yang wajib diikuti oleh semua karyawan Avnet. dan melakukan observasi dilapangan untuk melihat seberapa besar pemahaman karyawan akan perubahan yang terjadi. Adapun isi pelatihan yang diberikan Avnet, meliputi: pernyataan kembali alasan-alasan mengapa perlu melakukan perubahan dan faktor-faktor pendorongnya baik internal maupun eksternal, mendeskripsikan secara detail kondisi masa mendatang termasuk mendiskusikan tentang proses dan tujuan bisnis yang baru, teknologi dan peralatan-peralatan yang baru, menspesifikkan ketrampilan, pengetahuan dan perilaku-perilaku yang dibutuhkan oleh karyawan untuk mendukung perubahan dan apa yang harus dilakukan apabila proses atau peralatan yang baru tidak bekerja. Selain itu pimpinan Avnet juga memberikan project schedules, kebijakan dan prosedur yang baru, peran dan deskripsi jabatan-jabatan baru, layout ataupun desain pekerjaan yang baru sehingga memudahkan karyawan untuk belajar.

\section{ABILITY}

Pimpinan Avnet memahami bahwa perubahan secara rill hanya akan terjadi bila ditunjang dengan ability karyawan yang tinggi, baik berupa physical motors skill ability seperti penanganan produk, menjalankan peralatan baru, mengoperasikan mesin dan lain sebagainya, cognitive or analytical ability seperti ketrampilan memecahkan masalah, mengimplementasikan kebijakan-kebijakan dan prosedur bisnis baru, dan public speaking skill dan behavior yang terkait dengan transformasi pengetahuan ke dalam perilaku kerja yang baru seperti hubungan antar pribadi, dinamika kelompok dan menghentikan kebiasaan buruk.

\section{REINFORCEMENT}

\section{a. Reinforcement \& the Employee - Manager Disconnect}

Langkah terakhir dalam ADKAR Model adalah penguatan (reinforcement) atas perubahan yang terjadi. Ada berbagai bentuk penguatan yang dilakukan oleh pimpinan Avnet, baik berupa insentif maupun program penghargaan lainnya (recognition programs). Aplikasi dari program penguatan disesuaikan dengan prioritas karyawan dan para manajer serta kebijakan Avnet company dan karakteristik karyawan di masing-masing unit kerja.

\section{b. Most De-Motivating Job Factors}

Ada 5 hal utama yang disadari pimpinan Avnet sebagai factor yang tidak memotivasi karyawan dalam melakukan perubahan, yaitu kemampuan leadership yang buruk dari supervisor, peralatan dan perlengkapan kerja yang tidak tepat, lingkungan kerja yang buruk, benefit yang tidak tepat atau tidak ada dan insentif yang tidak relevan (irrelevant incentives). Pimpinan Avnet berusaha agar faktor-faktor di atas tidak dialami oleh para karyawannya. 


\section{c. The Effect of the Disconnect}

Dari hasil pengamatan di temukan beberapa hal yaitu para karyawan memiliki value yang berbeda dengan para manajer dan supervisor, para manajer sering underestimate terhadap pengaruh pribadi mereka dalam memotivasi dan memberikan penghargaan kepada karyawannya dan faktor-faktor yang memotivasi karyawan lebih banyak terkait dengan relationship dengan orang lain. Oleh karena itu dalam pemberian penguatan pun factor-faktor inipun menjadi pertimbangan pimpinan Avnet.

\section{d. The critical Take - Away for Change Management}

Selama proses perubahan, peran coaches dan supervisors sangat ditekankan oleh Avnet, karena hal tersebut merupakan salah satu channel terpenting untuk penguatan perubahan. Hal ini berarti ketrampilan dan kompetensi coaches dan supervisors dalam mengelola perubahan tidak dapat di abaikan maupun ditukar. Rencana pendampingan dan pelatihan yang terstruktur dari front-line supersivor dibuat oleh pimpinan Avnet dengan tujuan agar para karyawan dalam melewati proses perubahan dengan sukses.

\section{KESIMPULAN}

Secara ringkas dapat disimpulkan bahwa perubahan merupakan hal yang penting dan tidak bisa dihindari oleh suatu organisasi termasuk Avnet Company. Agar bisa survive dan unggul dalam bisnisnya, Avnet perlu melakukan perubahan dari perusahaan yang semula berbasis produk (product - based) ke perusahaan yang berbasis solusi (solution-based). Namun di sadari oleh para pimpinan Avnet tidak semua karyawan mau mendukung perubahan yang dilakukan. Salah satu pendekatan yang digunakan untuk menangani penolakan karyawan akan perubahan adalah pendekatan ADKAR Model yang menawarkan berbagai keunggulan dibandingkan dengan pendekatan lainnya. Namun di sadari pula bahwa model ini hanya akan optimal bila (1) tahapan pertama dan kedua (awareness dan desire) telah dilalui dengan baik; (2) change agent harus memiliki kompetensi (knowledge, skill, ability dan attitude) yang tinggi; (3) perubahan harus dimulai dari Top Management dan (4) adanya dukungan yang optimal dari seluruh tim manajemen Avnet baik dukungan sistem maupun dukungan finansial.

Secara teoritikal, pendekatan ADKAR Model yang digunakan merupakan bentuk perubahan yang direncanakan (planned changes) dan bersifat jangka panjang, karena proses perubahan yang dilakukan diakhiri dengan berbagai penguatan yang ditujukan agar membentuk pola kerja/budaya kerja dan norma-norma kerja yang baru dalam Avnet company. Secara teknikal implikasi penelitian ini adalah sebagai implementasi perubahan strategi bisnis dengan menggunakan model pendekatan ADKAR untuk menangani penolakan perubahan dari para karyawannya. Karena disadari bahwa IT security bisnis merupakan bisnis yang dinamis dan perubahan merupakan hal yang perlu dilakukan agar dapat mempertahankan dan meningkatkan konsumen di masa yang akan datang.

\section{DAFTAR REFERENSI}

Ashforth, B. E., \& Mael, F. A. (1998). The power of resistance: Sustaining valued identities. In R. M. Kramer \& M. A. Neale (Eds.) Power and influence in organizations. (pp. 89-119).

Bateman, Thomas S \& Carl.P Zeithaml, 1990, Management: Function \& Strategy, Homewood, IL ; Irwin

Coetsee,L (Summer, 1999), From resistance to commitment, Public Administration Quarterly, 204-222

Change Management Learning Center, di unduh Juni 2013

Dent, E \& Goldberg,S, (March, 1999), Challenging "resistance to change", Journal of Applied Behavioral Science 25-41

Folger, R \& Skarlicki, D. (1999), Unfaireness and resistance to change: hardship as mistreatment, Journal of Organizational Change Management, 35-50 


\section{Elsye Tandelilin}

Jeffrey M. Hiatt (2006), ADKAR: A Model For Change in Business, Government and Our Community, First Edition, Prosci Research Loveland, Colorado.

Greeberg Jerald \& Baron Robert.A (2000), Behavior in Organizations, Seventh Edition, Prentice-Hall, New Jersey

Hultman, K (Oct, 1995), Scaling the wall of resistance, Training \& Development, 15-22

Janzen, Felix (2001), The Age of Innovation, British Library Cataloguing in Publiscation Data, London

Maver, Rick, Oktober 1997, "Transforming Resistance", HR Focus

Piderit,S.K. (Oct, 2000), Rethinking resistance and recognizing ambivalence: a multidimensional view of attitudes toward an organizational change, Academy of Management - 794.A, 783

Robbins S, (2001), Organizational Behavior, Ninth Edition, Prentice Hall, New Jersey

Robbins S and Coulter M (2007) Management, Ninth Edition, Prentice Hall, New Jersey

Robbins Stephen S \& Judge Timothy A (2010), Organizational Behavior, Fourteenth Edition, Prentice Hall, New Jersey

Stauss and Corbin (2003), Basic of Qualitatif Research Techniques and Procedures For Developing Grounded Theory, Second Edition, Sage Publication, London

Senior Barbara, 2002, Organisational Change, Second edition, Prentice Hall, London. 
JURNAL

MANAJEMEN

TEORI DAN TERAPAN

Journal of Theory \& Applied Management
Department of Management

Faculty of Economics \& Business Universitas Airlangga

ISSN 1979-3650 (print) and ISSN 2548-2149 (online) 
Journal Profile

\section{Jurnal Manajemen Teori dan Terapan}

eISSN : 25482149 I pISSN : 19793650

Science Education

Universitas Airlangga

\section{Cînta}

\section{S3}

Sinta Score

\section{v Paruda}

Indexed by GARUDA

21

H-Index

19

H5-Index

2105

Citations 


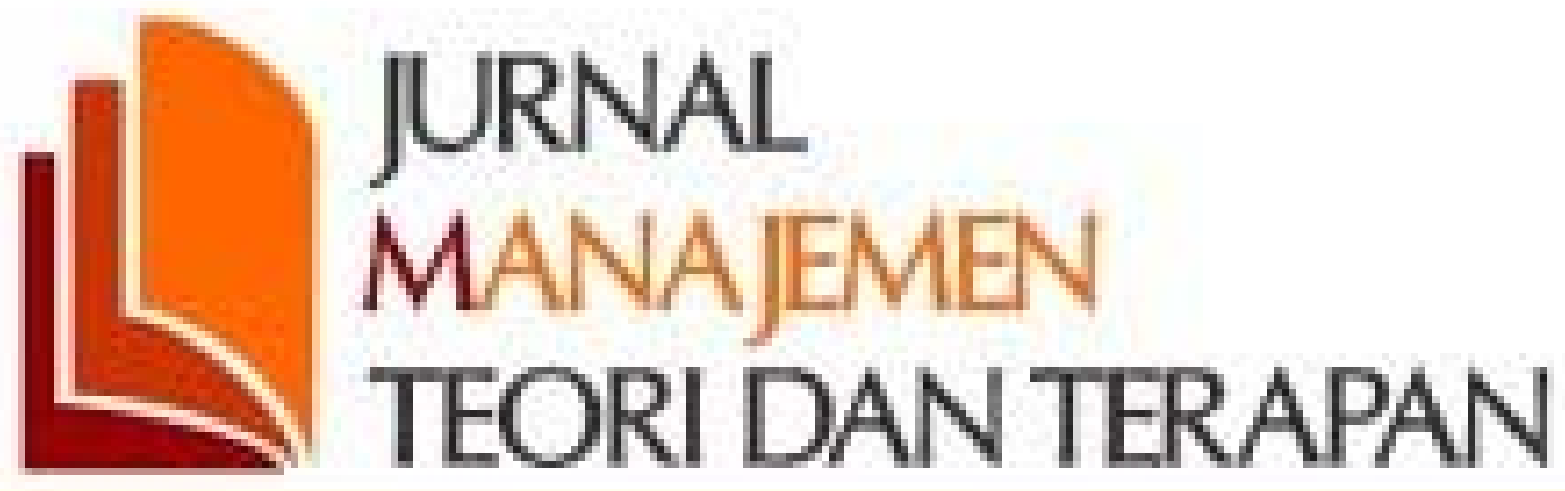

\section{Journal of Theory \& Applied Management}

Penerbit:

\section{Website $\mid$ Editor URL}

Address:

Surabaya

Email:

Phone:

Search..

Q

$$
\begin{array}{lllllllll}
\mathbf{K} & \ll & 1 & 2 & 3 & 4 & 5 & \gg & \boldsymbol{Y}
\end{array}
$$

Page 1 of 24 / Total Records : 236

Publications

Citation

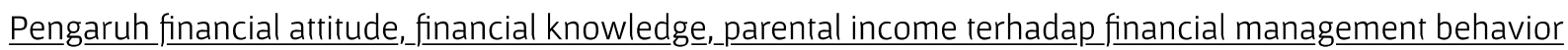
I Herdjiono, LA Damanik

Jurnal Manajemen Teori dan Terapan 9 (3), 2016

Faktor-faktor yang dipertimbangkan investor dalam melakukan investasi

LA Mahastanti

Jurnal Manajemen Teori Dan Terapanl Journal of Theory and Applied Management ..., 2011 
Pengaruh mekanisme corporate governance terhadap kinerja keuangan badan usaha

F Puspitasari, E Ernawati

Jurnal Manajemen Teori dan Terapan 3 (2), 2010

Pengaruh Kualitas Produk Terhadap Kepuasan, Reputasi Merek dan Loyalitas Konsumen Jamu Tolak Angin PT.

Sido Muncul

B Hermawan

Jurnal Manajemen Teori dan Terapan 4 (2), 2011

Pengaruh disiplin kerja terhadap kinerja pegawai di biro pelayanan sosial dasar sekretariat daerah provinsi

Jawa Barat

A Pangarso, PI Susanti

Jurnal Manajemen Teori dan Terapan 9 (2), 2016

Penerapan Technology Acceptance Model (TAM) dalam pengujian model penerimaan sistem informasi

keuangan daerah

F Sayekti, P Putarta

Jurnal Manajemen Teori dan Terapanl Journal of Theory and Applied Management ..., 2016

Corporate Governance dan Pengungkapan Corporate Social Responsibility_pada Perusahaan Go-Public Di

Bursa Efek Indonesia

IM Sudana, PA Arlindania

Jurnal Manajemen Teori dan Terapan I Journal of Theory and Applied ..., 2011

Strategi konservasi kebudayaan lokal Yogyakarta

A Soeroso, YS Susuilo

Jurnal Manajemen Teori dan Terapan 1 (2), 2008

Pengaruh dewan komisaris, proporsi komisaris independen, terhadap kinerja perusahaan

BPD Putra

Jurnal Manajemen Teori dan Terapan 8 (2), 2015

Kualitas Produk, Citra Merek Dan Persepsi Harga Terhadap Proses Keputusan Pembelian Konsumen Sepeda

Motor Matic "Honda"

N Fatmawati, E Soliha

Jurnal Manajemen Teori dan Terapanl Journal of Theory and Applied Management ..., 2017

Page 1 of 24 I Total Records : 236

Citation Statistics 


\section{TEORI DANTERAPAN}

Journal of Theory \& Applied Management

ISSN 1979-3650 (print) and ISSN 2548-2149 (online)

\section{HOME ABOUT LOGIN REGISTER SEARCH CURRENT ARCHIVES ANNOUNCEMENTS}

Home > Vol 14, No 2 (2021)

\section{JURNAL MANAJEMEN TEORI DAN TERAPAN}

Jurnal Manajemen Teori \& Terapan | Journal of Theory \& Applied Management (JMTT), with registered number ISSN 1979-3650 (Print) and ISSN 2548-2149 (Online), is a peer-reviewed journal published three times a year (January-April, May-August, and September-December) by Universitas Airlangga, Department of Management in collaboration with the Forum Manajemen Indonesia (FMI). JMTT is intended to be the journal for publishing articles reporting the results of research on business.

The JMTT invites manuscripts in the various topics include, but not limited to, functional areas of marketing management, finance management, strategic management, operation management, human resource management, e-business, knowdedge management, management accounting, management control system, management information system, international business, business economics, managerial economics, business ethics and sustainable, and entrepreneurship.

This journal is currently indexed in:

- Science and Technlogy Index (SINTA 3)

- The Directory of Open Access Journals (DOAJ)

- INDEX-COPERNICUS International

- Google Scholar

- Garba Rujukan Digital (GARUDA)

- CROSSREF (DOI)

- DIMENSIONS

- Bielefeld Academic Search Engine (BASE)

- Indonesian Scientific Journal Database (ISJD)

USER

Username

Password

Remember me

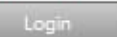

\section{AUTHOR INFO}

Author Guidelines

Online Submission

Article Template (EN)

Article Template (ID)

Plagiarism Policy

Article Proccessing Charge

JOURMAL POLICY

Focus and Scope

Publication Ethics

Peer Review Process

Open Access Statement 


\section{EDITORIAL TEAM}

\section{EDITOR IN CHIEF}

Prof. Dr. Badri Munir Sukoco, Scopus ID: 25823403000, Universitas Airlangga, Indonesia

\section{MANAGING EDITORS}

Rahmat Heru Setianto, SCOPUS ID: 55490516000, Universitas Airlangga, Indonesia Nidya Ayu Arina, SCOPUS ID: 57214671132, Universitas Airlangga, Indonesia

Raras Kirana Wandira, SCOPUS ID: 57214664996, Universitas Airlangga, Indonesia Erika Sefila Putri, Universitas Airlangga, Indonesia

\section{EDITORIAL BOARD}

Assoc. Prof. Dr. Zulnaidi Yaacob, SCOPUS ID: 36142496900, Universiti Sains Malaysia,, Malaysia Assist. Prof. Dr. Mihai Tichindelean, SCOPUS ID: 57207849143, Universitatea Lucian Blaga din Sibiu, Romania

Prof. Dr. Christopher Gan, SCOPUS ID: 14626363200, Lincoln University, New Zealand

Assist. Prof. Dr. Abdelghani Echchabi, SCOPUS ID: 55005973700, Higher Colleges of Technology Abu Dhabi, United Arab Emirates

Assist. Prof. Dr. Muhammad Rizky Prima Sakti, SCOPUS ID: 57192068514, University College of Bahrain, Bahrain

Assoc. Prof. Dr. Muhamad Abduh, SCOPUS ID: 6508136735, Universiti Brunei Darussalam, Brunei Darussalam

Asst. Prof. Dr. Abdul Rahim Ridzuan, SCOPUS ID: 57201919567, Universiti Teknologi Mara, Malaysia

Asst. Prof. Dr. Forbis Ahmed, SCOPUS ID: 50261007500, Management and Sciences University, Malaysia

Prof. Dr. Tanti Handriana, SCOPUS ID: 24832940700, Universitas Airlangga, Indonesia

Assist. Prof. Dr. Hendra Wijaya, SCOPUS ID: 57195045588, Widya Mandala Catholic University, Indonesia

Assoc. Prof. Dr. Praptini Yulianti, SCOPUS ID: 57210320181, Universitas Airlangga,, Indonesia Assoc. Prof. Dr. Masmira Kurniawati, SCOPUS ID: 57210315804, Universitas Airlangga, Indonesia

\section{Indexed by:}

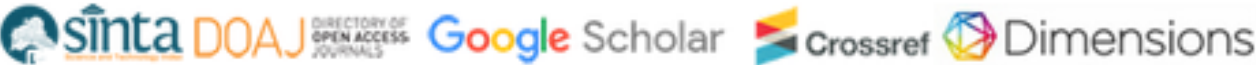

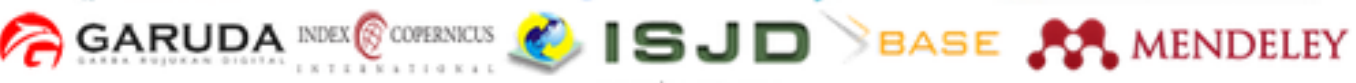
PKP INDEX 


\section{VOL 6, NO 2 (2013)}

\section{TABLE OF CONTENTS}

\section{ARTICLES}

Pengaruh Corporate Social Responsibility (CSR) Pada Market Value Added (MVA) Perusahaan Manufaktur Dan Pertambangan

d. $10.20473 / \mathrm{jm} t \mathrm{t} . \mathrm{v} 6 \mathrm{i} 2.2664$

3 Rezi Setin Novian, Santi Novita

Pengaruh Kepemimpinan Dan Lingkungan Kerja Terhadap Komitmen Organisasional Dan Kinerja Karyawan PT. Sumber Djantin Di Kalimantan Barat

d. $10,20473 / \mathrm{jm}$ tt.v6i2.2665

3 Ahmad Shalahuddin

KEBERHASILAN MELAKUKAN PERUBAHAN MELALUI ADKAR MODEL Studi KasUS Avnet Information Security Company

d.

$10.20473 / \mathrm{jm} t \mathrm{tt} . \mathrm{vi} 2.2666$

3 Elsye Tandelilin

Strategi Aktif (Moving Average) Dan Strategi Pasif (Buy-And-Hold Strategi) Pada Pembentukan Portofolio Periode 2 Januari 2012 - 28 Desember 2012

d. $10.20473 / \mathrm{jm} t \mathrm{t} . \mathrm{v} 6 \mathrm{i} 2.2667$

8 Loddy Li Putra, Werner R. Murhadi, Putu Anom Mahadwartha

Pengaruh Identitas Sosial Dan Co-Creation Terhadap Niat Berperilaku Anggota Komunitas Online VW: Efek Moderasi Nostalgia

$10.20473 / j \mathrm{mtt} . v 6 \mathrm{i} 2.2668$

3 Badri Munir Sukoco, Untung Teko TP

Pembingkaian Pesan Dan Persepsi Risiko Psikologis Pada Isu Konsumen Hijau

d. $10.20473 / \mathrm{jm}$ tt.v6i 2.2669

8 Euis Soliha, H. Sophiyanto Wuryan

Indexed by:

Csinta DOAJ Google Scholar crossret Dimensions

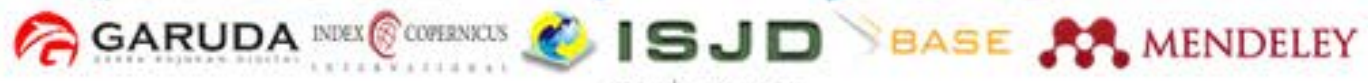

PKPINDEX 